\title{
ENHANCED PRODUCTION OF INDUSTRIAL ENZYMES IN MUCOROMYCOTINA FUNGI DURING SOLID-STATE FERMENTATION OF AGRICULTURAL WASTES/BY-PRODUCTS
}

\author{
Miklós Takó, ${ }^{1}$ * Alexandra Kotogán, ${ }^{1}$ Judit Krisch, ${ }^{2}$ Csaba Vágvölgyi, ${ }^{1}$ \\ Keshab C. MONDAL ${ }^{3}$ and TAMÁs PAPP ${ }^{1}$ \\ ${ }^{1}$ Department of Microbiology, Faculty of Science and Informatics, University of Szeged, \\ Szeged, Hungary \\ ${ }^{2}$ Institute of Food Engineering, Faculty of Engineering, University of Szeged, Szeged, Hungary \\ ${ }^{3}$ Department of Microbiology, Vidyasagar University, Midnapore, West Bengal, India
}

(Received: October 15, 2014; accepted: December 15, 2014)

\begin{abstract}
Cellulolytic, lipolytic and proteolytic enzyme production of zygomycetes Mucor corticolus, Rhizomucor miehei, Gilbertella persicaria and Rhizopus niveus were investigated using agro-industrial wastes as substrates. Solid-state cultures were carried out on untreated corn residues (stalk and leaf) as single substrate (SSF1) or corn residues and wheat bran in mixed fermentation (SSF2). Rapid production of endoglucanase (CMCase) was observed with maximal activity reaching after about 48-h fermentation, while cellobiohydrolase $(\mathrm{CBH})$ and $\beta$-glucosidase enzymes generally had their peak after 72-h incubation. Highest filter paper degrading (FPase), CMCase, $\mathrm{CBH}$ and $\beta$-glucosidase activities obtained were $\left(\mathrm{U} \mathrm{g}^{-1}\right.$ dss) 17.3, 74.1, 12.2 and 158.3, for R. miehei, G. persicaria, M. corticolus and Rh. niveus, respectively. M. corticolus proved to be the best lipolytic enzyme producer in SSF1 presenting $447.6 \mathrm{U} \mathrm{g}^{-1}$ dss yield, while $R$. miehei showed $517.7 \mathrm{U} \mathrm{g}^{-1}$ dss activity in SSF2. Rh. niveus exhibited significantly greater protease production than the other strains. Suc-AAPF- $p$ NA hydrolyzing activities of this strain were 1.1 and $1.96 \mathrm{U} \mathrm{g}^{-1}$ dss in SSF1 and SSF2, respectively. We conclude that the used corn stalk and leaf residues could potentially be applicable as strong inducers for cellulase and lipase production by Mucoromycotina fungi.
\end{abstract}

Keywords: Zygomycetes - hydrolytic enzymes - corn stalk and leaf - wheat bran - mixed fermentation

\section{INTRODUCTION}

Agro-industrial processes produce large quantities of corn stalk and leaf residues as plant-waste materials each year. Solid-state fermentation (SSF) holds huge potential for bioconversion of cellulosic materials and for high-yield enrichment of biomassdegrading enzymes $[2,33]$. Therefore, this technology provides an alternative and economical approach to exploit of these renewable and inexpensive resources. Although corn stalk is commonly used for production of biofuels and other chemicals [26], direct bioconversion has poorly been studied up to now. Moreover, in most

\footnotetext{
*Corresponding author; e-mail address: tako78@bio.u-szeged.hu
} 
enzymatic digestibility researches, the raw substrate is subjected to chemical, biological or steam explosion pre-treatments $[19,36]$.

Conversion of cellulosic biomass to ethanol requires enzymatic hydrolysis of this biopolymer to fermentable glucose as a first step. This degradation is carried out by cellulases that are complex mixtures of enzymes with different specificities to hydrolyze the $\beta-1,4$-glycosidic linkages of cellulose. There are three major types of cellulolytic activities in this extensively studied multienzyme complex [15]: endoglucanases or CMCases (EC 3.2.1.4), cellobiohydrolases (EC 3.2.1.91) and $\beta$-glucosidases (EC 3.2.1.21). Cellulases useful in industrial processes are mainly extracellular enzymes secreted by different types of fungi [5].

Fungal lipases and proteases also have great importance in microbial degradation of agro-industrial wastes [4, 27]. Lipases (EC 3.1.1.3) catalyze the hydrolysis of triacylglycerols, the major constituents of fats and oils, which can widely be found in plant-waste residues. Outcomes of this hydrolysis are free fatty acids, glycerol and partial acylglycerols, which are easily utilizable energy resources for microorganisms. Microbial proteases are capable to catalyze the total hydrolysis of proteins of plant-waste biomass.

Mucoromycotina is a large group of zygomycetes fungi, which are primarily saprotrophic having well-demonstrated growth characteristics on various low-cost resources. Several zygomycetes are recognized as valuable sources of extracellular hydrolases, some of which are utilized in industrial applications [11]. Crude hydrolase preparations derived from fungal sources may efficiently support biotechnological processes. For instance, addition of crude cellulase cocktail to cellulosic residues makes the saccharification process faster and thus bioethanol production can be cost effective and eco-friendly [26]. While the plant-waste induced secretion of the abovementioned hydrolases has extensively been studied in some filamentous fungi $[8,25$, $28]$, much less is known on zygomycetes in this regard [13, 24, 35]. This study has focused to cellulase, lipase and protease production of selected Mucoromycotina strains using corn stalk and leaf plant-wastes as substrates in SSF. At the same time, the yield-enhancing effect of wheat bran was also explored in mixed fermentation assays.

\section{MATERIALS AND METHODS}

\section{Organisms and fermentation materials}

Mucor corticolus (SZMC 12031), Rhizomucor miehei (SZMC 11005), Gilbertella persicaria (SZMC 11086) and Rhizopus niveus (SZMC 13625) strains were used. Fungal isolates were deposited in the Szeged Microbiological Collection (SZMC, Szeged, Hungary). For fermentation, equal amount of dry corn stalk and leaf were cut into small pieces. These chopped corn residues were then briefly milled in a commercial mill into particles of $1.5 \mathrm{~mm}$ mean diameter. Wheat bran was purchased in a local market, and was added in 1:1 ratio to the corn residues in the case of mixed substrate fermentation experiments. 


\section{Solid-state fermentation}

SSFs were carried out in 250-mL Erlenmeyer flasks containing $5 \mathrm{~g}$ of milled corn stalks and leaves (designated as SSF1) or a mixed substrate (designated as SSF2). Five $\mathrm{mL}$ distilled water was added to moisturize the solids, and then the media were autoclaved at $121{ }^{\circ} \mathrm{C}$ for $30 \mathrm{~min}$. After cooling, each flask was inoculated with $10^{6}$ sporangiospores and incubated at $25^{\circ} \mathrm{C}$ or $37^{\circ} \mathrm{C}$ (in the case of $R$. miehei) for 12 days. Crude enzyme extraction was performed on every second day with $50 \mathrm{~mL}$ of distilled water by shaking at $4{ }^{\circ} \mathrm{C}$ for $3 \mathrm{~h}$. Suspensions were squeezed through a filter cloth, then, filtered with Whatman No. 1 paper and centrifuged at $16,200 \times g$ for 20 min at $4{ }^{\circ} \mathrm{C}$. Enzyme activities were determined in the clear extracts and were expressed as $\mathrm{U} \mathrm{g}^{-1}$ of dry substrate (dss).

\section{Cellulolytic enzyme assay}

Filter paper degrading activity (FPase) was evaluated using Whatman No. 1 filter paper. Endoglucanase (CMCase) activity was analyzed using carboxymethyl cellulose (CMC; Sigma-Aldrich) as a substrate. The reaction mixtures consisted of $200 \mu \mathrm{L}$ sodium acetate buffer $(0.1 \mathrm{M}, \mathrm{pH} 5.5), 50 \mu \mathrm{L}$ crude enzyme extract and $2.5 \mathrm{mg}$ filter paper or $1 \%$ CMC. In the case of the FPase activity, mixtures were incubated at $50{ }^{\circ} \mathrm{C}$ for $1 \mathrm{~h}$. CMCase activity was studied by incubation at the same temperature for $30 \mathrm{~min}$. Concentration of reducing sugar was determined by the dinitrosalicylic acid (DNS) method [20]. One unit of each activity was defined as the amount of enzyme that released $1 \mu \mathrm{mol}$ of glucose equivalent from the respective raw substrate per minute under the assay conditions. $\beta$-Glucosidase and cellobiohydrolase $(\mathrm{CBH})$ activities were measured using $p$-nitrophenyl- $\beta$-D-glucopyranoside ( $p$ NPG; Sigma-Aldrich) and $p$-nitrophenyl- $\beta$-D-cellobioside ( $p$ NPC, Sigma-Aldrich) as substrate, respectively. The reaction mixture contained $800 \mu \mathrm{L}$ sodium acetate buffer $(0.1 \mathrm{M}, \mathrm{pH} 5.5)$, $100 \mu \mathrm{L} p$ NPG $(7 \mathrm{mM})$ or $p$ NPC $(4 \mathrm{mM})$ and $100 \mu \mathrm{L}$ crude enzyme extract. Reaction mixtures were incubated for $30 \mathrm{~min}$ at $50{ }^{\circ} \mathrm{C}$ because $\beta$-glucosidases of the used strains had their maximum activity under this condition [30]. The reaction was stopped by adding $2 \mathrm{~mL}$ of $0.1 \mathrm{M}$ sodium carbonate, and the released $p$-nitrophenol $(p N P)$ was measured spectrophotometrically using a Jenway 6800 Double Beam Spectrophotometer (Jenway, Bibby Scientific) at $405 \mathrm{~nm}$. One unit of enzyme activity was defined as the amount of enzyme that liberated $1 \mu \mathrm{mol}$ of $p$ NP per min.

\section{Lipolytic activity assay}

Lipolytic activity was determined after Kotogán et al. [17] using $p$-nitrophenyl-palmitate ( $p$ NPP, Sigma-Aldrich). Incubations were carried out at $25{ }^{\circ} \mathrm{C}$ for G. persicaria, M. corticolus and Rh. niveus and $37^{\circ} \mathrm{C}$ for $R$. miehei enzymes. One unit of enzyme activity was defined as mentioned above. 


\section{Proteolytic activity assay}

Extracellular proteolytic activity of the isolates was studied by the use of chromogenic peptidyl- $p$-nitroanilide substrates. Activity of trypsin-like proteases was measured with N-alpha-benzoyl-L-Arg- $p$-nitroanilide (Bz-R-pNA) and N-alpha-benzoyl-PheVal-Arg- $p$-nitroanilide (Bz-FVR- $p$ NA), while chymotrypsin-like protease activity was determined by N-Succinyl-Phe- $p$-nitroanilide (Suc-F- $p$ NA) and N-Succinyl-AlaAla-Pro-Phe- $p$-nitroanilide (Suc-AAPF- $p$ NA). All of these substrates were purchased from Sigma-Aldrich. Reaction mixtures were consisted of $160 \mu \mathrm{L}$ of distilled water (pH 7.0), $20 \mu \mathrm{L}$ of substrate $(5 \mathrm{mM})$ and $20 \mu \mathrm{L}$ of crude enzyme extract. Mixtures were incubated at 25 or $37^{\circ} \mathrm{C}$ for $30 \mathrm{~min}$ in 96-well microtiter plates, and the reaction was stopped by adding $50 \mu \mathrm{L}$ of $0.1 \mathrm{M}$ sodium carbonate. The released $p$-nitroaniline ( $p$ NA) was measured spectrophotometrically (ASYS Jupiter HD, ASYS Hitech) at $410 \mathrm{~nm}$. According to the manufacturer's instruction, the molar absorption coefficient of $8800 \mathrm{M}^{-1} \mathrm{~cm}^{-1}$ for $p \mathrm{NA}$ was used to calculate the enzyme activity. One unit of enzyme activity was defined as the amount of enzyme that liberated $1 \mu \mathrm{mol}$ of $p \mathrm{NA}$ per min.

\section{Statistical analysis}

All experiments were performed in triplicates. Standard deviations of mean values were calculated using Microsoft Office Excel 2007 function and the Sigma Plot (USA) software was used for statistical significance analyses.

\section{RESULTS}

\section{Total cellulolytic activity}

In both SSF1 and SSF2, maximal amount of reducing sugar was detected on the second day (Fig. 1). The activity was markedly decreased at the fourth day, which was not observed when corn residue was used as the sole substrate (data not shown). FPase activity of $M$. corticolus had similar rate in both SSF1 and SSF2 during the whole fermentation period. Interestingly, $M$. corticolus had the lowest activity in the wheat bran-supplemented medium among the investigated fungi ( $6.6 \mathrm{U} \mathrm{g}^{-1}$ dss) but it showed outstanding FPase capacity when only corn residues were used $\left(7.2 \mathrm{U} \mathrm{g}^{-1}\right.$ dss). The order of the FPase activities in the crude extracts after SSF2 was R. miehei $>$ G. persicaria $>R h$. niveus $>M$. corticolus, while it was $M$. corticolus $>$ $R h$. niveus $>$ G. persicaria $>R$. miehei in the SSF1 system. 


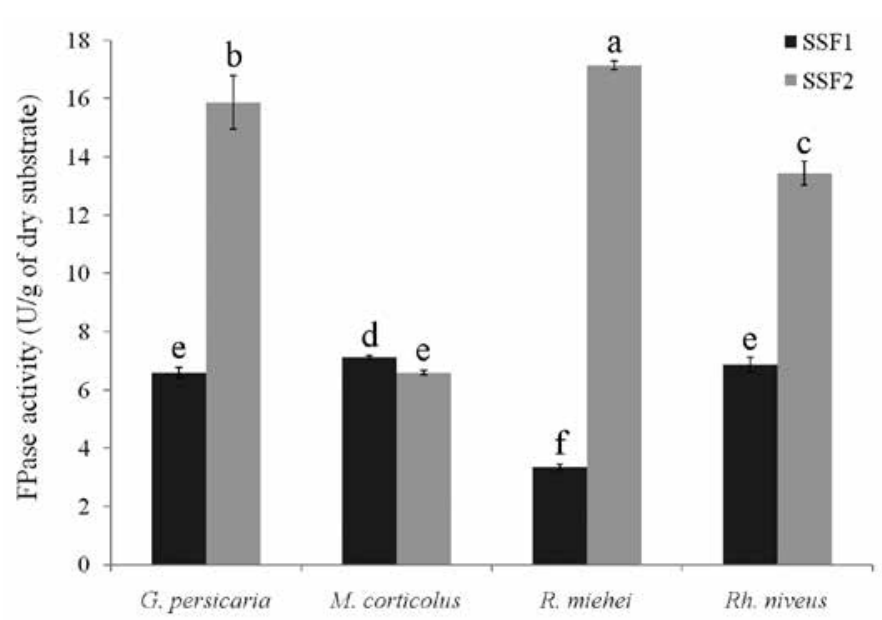

Fig. 1. Filter paper (FPase) activity of zygomycetes strains in corn residue-based (SSF1) and mixed (corn residue and wheat bran) substrate-based (SSF2) solid-state fermentations. Values were measured on the 2 nd day of the fermentation. Bars represent SD values of replicates. Different letters over the bars indicate significant differences $(\mathrm{P}<0.05)$ in Duncan's multiple range test

\section{Endoglucanase activity}

CMCase production of the isolates using SSF1 and SSF2 fermentation systems is shown in Table 1. In SSF2, each isolate showed the highest enzyme yield at the second day of the cultivation. After 48-h incubation, the CMCase activity in the crude extracts was G. persicaria $>$ Rh. niveus $>R$. miehei $>M$. corticolus. If longer incubation period was applied, enzyme production of G. persicaria and $R h$. niveus isolates remarkably decreased; during a 10-day incubation, their CMCase activities of 74.1 and $59.5 \mathrm{U} \mathrm{g}^{-1}$ dss measured on the second day reduced to 52.4 and $46.8 \mathrm{U} \mathrm{g}^{-1}$ dss, respectively. In contrasts, after a significant drop by the sixth day (50.5 to $18.6 \mathrm{U} \mathrm{g}^{-1}$ dss), a slight increase in the enzyme activity of the $R$. miehei isolate was detected on the tenth day (25.7 $\left.\mathrm{U} \mathrm{g} \mathrm{g}^{-1} \mathrm{dss}\right)$. With the exception of $G$. persicaria, usage of SSF1 medium resulted in lower CMCase activities on the first phase of the incubation than those measured on the sixth day. In this medium, the relative CMCase activity in the crude extracts was G. persicaria $>R h$. niveus $>M$. corticolus $>R$. miehei. CMCase activities of $R$. miehei showed big differences in mixed substrate and corn-residue based media, which were not detected in the other tested crude extracts.

\section{Cellobiohydrolase activity}

Table 1 shows the time course profiles of CBH activities during the SSFs. It can firstly be observed that the $p$ NPC hydrolysis in the crude extract of $M$. corticolus was at least 2-3 times higher than those detected by the other strains in SSF1. Product 


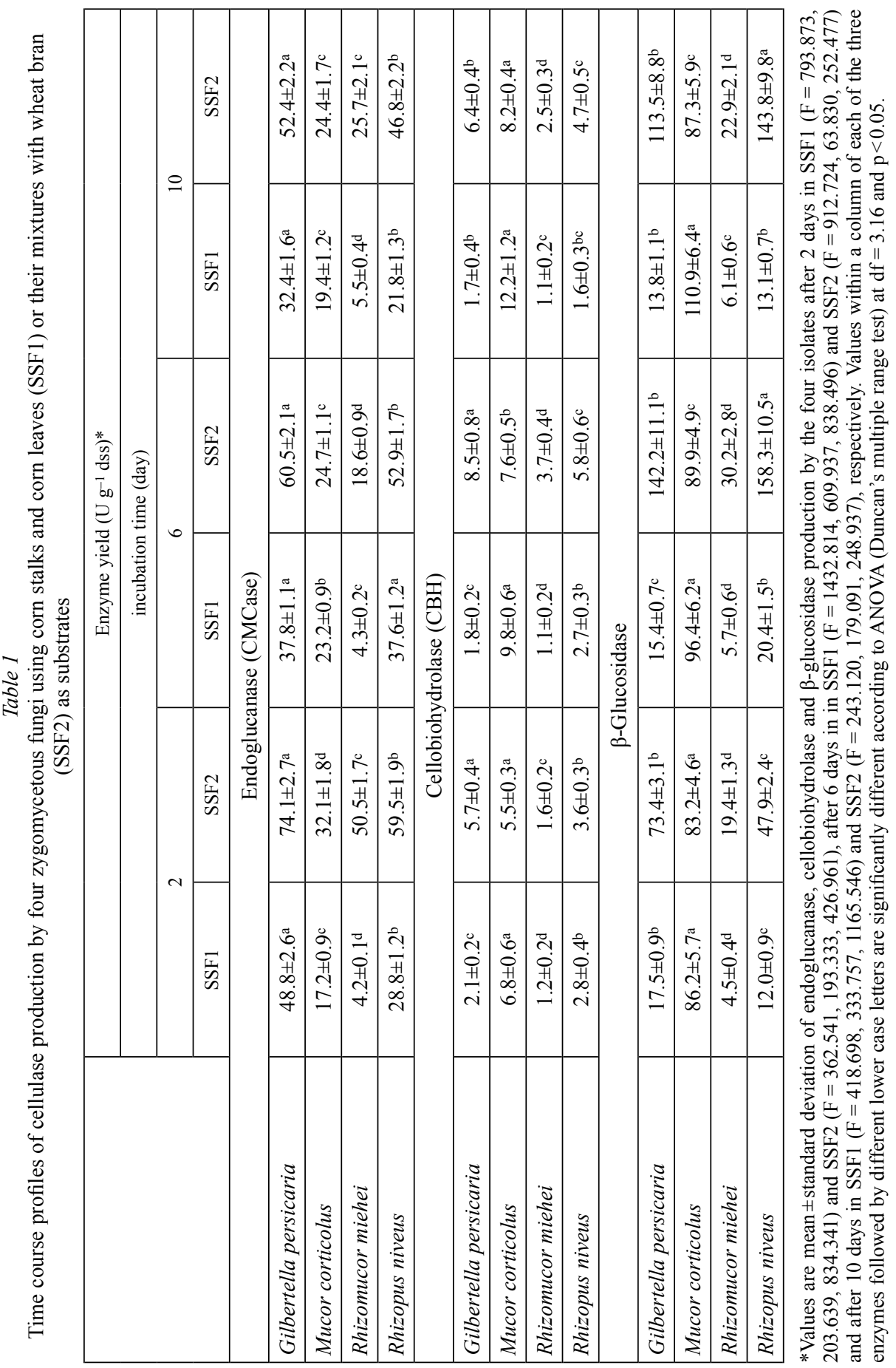

Acta Biologica Hungarica 66, 2015 
yield of this fungus had continuously increased exceeding $12.2 \mathrm{U} \mathrm{g}^{-1}$ dss activity to the tenth day of incubation. On the contrary, CBH production of the other strains displayed a decrease to the end of the fermentation. Anyway, the abovementioned M. corticolus $\mathrm{CBH}$ activity was the best value that could be measured in the two fermentation systems. In SSF2, G. persicaria, R. miehei and Rh. niveus showed their maximum $\mathrm{CBH}$ activity on the sixth day $\left(8.5,3.7\right.$ and $\left.5.8 \mathrm{U} \mathrm{g}^{-1} \mathrm{dss}\right)$ while $M$. corticolus reached it on the tenth day $\left(8.2 \mathrm{U} \mathrm{g}^{-1} \mathrm{dss}\right)$. Because maximal $\mathrm{CBH}$ concentrations were reached at different days of culturing by each strain, determination of relative catalytic activity is difficult to this enzyme.

\section{$\beta$-Glucosidase activity}

$\beta$-Glucosidase activity of the tested isolates was generally higher than the CMCase and $\mathrm{CBH}$. Best activity was $158.3 \mathrm{U} \mathrm{g}^{-1}$ dss presented by Rh. niveus in SSF2. All strains exhibited its maximal enzyme activity on the sixth day of SSF2 where the relative $\beta$-glucosidase activity was $R h$. niveus $>G$. persicaria $>M$. corticolus $>$ $R$. miehei. A slight decrease in the enzyme activity could be observed after sixth day. In contrast to SSF2, $\beta$-glucosidase activity in SSF1 varied and maximum enzyme activities were measured after different incubation periods. For instance, M. corticolus and $R$. miehei demonstrated their best enzymatic activity on the tenth day (110.9 and $6.1 \mathrm{U} \mathrm{g}^{-1} \mathrm{dss}$ ), while G. persicaria and Rh. niveus exhibited their highest activity on the second (17.5 $\left.\mathrm{U} \mathrm{g}^{-1} \mathrm{dss}\right)$ and the sixth day $\left(20.4 \mathrm{U} \mathrm{g}^{-1} \mathrm{dss}\right)$, respectively. It is

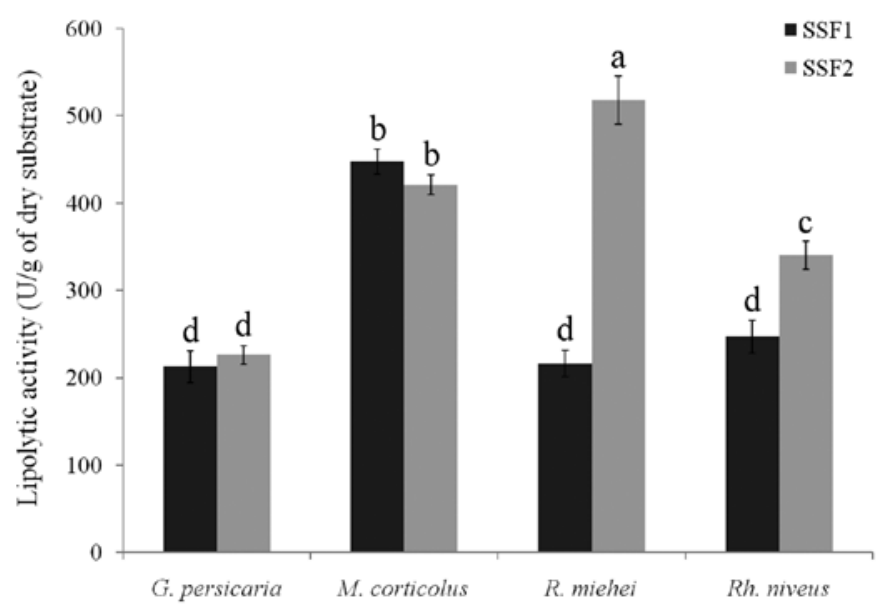

Fig. 2. Maximal lipolytic activity of zygomycetes strains in corn residue-based (SSF1) and mixed (corn residue and wheat bran) substrate-based (SSF2) solid-state fermentations. Presented activities were measured on the 2nd day of fermentation by G. persicaria, and 12th day by M. corticolus, R. miehei and Rh. niveus. Bars represent SD values of replicates. Different letters over the bars indicate significant differences $(\mathrm{P}<0.05)$ in Duncan's multiple range test 
worth to mention that similar to its $\mathrm{CBH}$ production, $\beta$-glucosidase yield of $M$. corticolus in SSF1 was superior to that reached in SSF2. This enhanced activity maintained throughout the whole cultivation period.

\section{Lipolytic enzyme production}

Lipase yield of $G$. persicaria reached its maximum after two-day cultivation; $M$. corticolus, $R$. miehei and $R h$. niveus had their maximum enzyme activity on the 12th incubation day. Cultivation of $R$. miehei and Rh. oryzae in SSF2 resulted considerably higher lipase yield than in SSF1. As shown in Figure 2, R. miehei had the highest $p$ NPP hydrolyzing activity (518 $\mathrm{U} \mathrm{g}^{-1} \mathrm{dss}$ ) after fermentation for 12 days. Almost 2.5 times higher lipase yield was detected at this fungus in SSF2 compared to that in SSF1. M. corticolus was the best lipase producer in fermentation system containing only corn residues as substrate (see SSF1 in Fig. 2). The presented $448 \mathrm{U} \mathrm{g}^{-1}$ dss enzyme yield was about 2 times higher than those measured in the crude extracts of the other strains. The relative lipase yield was $M$. corticolus $>R h$. niveus $>$ $R$. miehei $>$ G. persicaria in SSF1, and $R$. miehei $>M$. corticolus $>$ Rh. niveus $>$ G. persicaria in SSF2.

\section{Proteolytic enzyme production}

Protease production of the Rh. niveus strain was outstanding among the tested isolates in both SSF1 and SSF2. However, only the assay of Suc-AAPF- $p$ NA hydrolysis showed efficient results by this fungus, which refers to a strong chymotrypsin-like

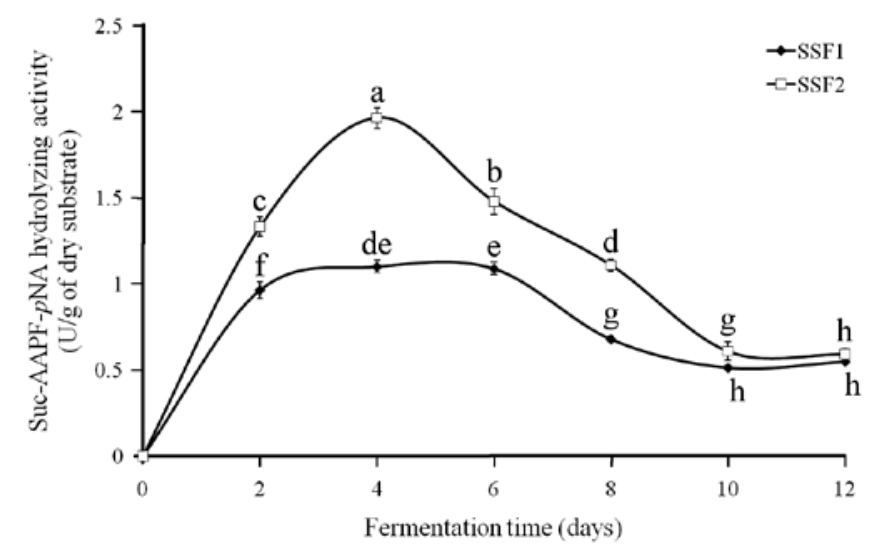

Fig. 3. Time course of Suc-AAPF- $p$ NA degrading protease production by Rh. niveus under corn residuebased (SSF1) and mixed (corn residue and wheat bran) substrate-based (SSF2) solid-state fermentations. Bars represent SD values of replicates. Different letters on the bars are significantly different $(P<0.05)$ in Duncan's multiple range test 
proteolytic activity. The presented $1.96 \mathrm{U} \mathrm{g}^{-1}$ dss maximum proteolytic activity was generally 4 to 10 times higher than those of the other isolates. G. persicaria also had mentionable Suc-AAPF- $p$ NA hydrolyzing activity on the fourth day in SSF2 (0.52 U $\mathrm{g}^{-1}$ dss). Chymotrypsin-like proteolytic activity of the other tested strains was remained in the range from 0.15 to $0.39 \mathrm{U} \mathrm{g}^{-1}$ dss. The Bz-R-pNA and Bz-FVR- $p$ NA hydrolyzing activities generally varied between 0.024 and 0.37 and 0.014 and $0.43 \mathrm{U}$ $\mathrm{g}^{-1}$ dss, respectively, which indicated moderate trypsin-like proteolytic activities of the isolates. M. corticolus showed the highest activity values for both trypsin substrates. Figure 3 depicts the time course profile of chymotrypsin-like protease activity of $R h$. niveus during the 12-day incubation period. The enzyme production reached a maximum level after $96 \mathrm{~h}$ followed by a slight decrease up to the end of the fermentation. Similarly to the most of the other tested enzymes, SSF2 proved to be a better medium for chymotrypsin-like protease production.

\section{DISCUSSION}

Isolates selected for this study proved to be good extracellular $\beta$-glucosidase and/or lipase producers in our previous experiments $[17,31]$. In that studies, SSF on wheat bran generally resulted in significantly higher enzyme activities than the liquid cultures. Hence, two SSF systems were tested in the present assays: a single medium of chopped corn stalks and leaves (SSF1) and a mixed substrate containing corn residues and wheat bran (SSF2).

Each isolate showed intensive growth under the applied culturing conditions, but they revealed noticeable differences in the production of the tested hydrolases. Generally, higher enzyme activities could be detected when SSF2 medium was used. It might be attributed to the nutritious properties of wheat bran. This plant residue supplies the fungi with convenient amount of nutrients, such as proteins, carbohydrates, fats, fiber, ash, minerals; furthermore, it has suitable particle size and porosity for oxygen supply [3]. Due to these properties, the crude fiber content of wheat bran might be highly accessible for the fungal exoenzymes. Our studies with different proportions of wheat bran also strengthened this suggestion (results not shown). In that assays, higher wheat bran concentration caused increased cellulase and lipase activities while proteolytic enzyme secretion did not change. In light of this viewpoint, it is important to note that the FPase activities on SSF1 were higher than those reported recently for other fungal cellulases on rice straw [22,29] and oil palm trunk [1]. Kaur et al. [16] also used plant residue substrate in SSF to evaluate the cellulase production of mutants derived from heterokaryotic Aspergillus strains. Though CMCase, $\mathrm{CBH}$ and $\beta$-glucosidase activities of the 'A' (III) mutant developed in that study were 3.28, 5.32 and 7.03 times higher, respectively, than our best yields obtained for these enzymes (Table 1), FPase activities of G. persicaria, R. miehei and $R h$. niveus on SSF2 were superior than this mutant strain. Cellulase preparations from these strains may be feasible additives for fast enzymatic pre-treatment of cellulosic wastes. This process is a critical step for bioethanol production, and requires enhanced 
FPase activity in the crude cellulase extract [7]. Nevertheless, considering the FPase yields obtained on SSF1, the chopped corn stalk and leaf residues may also be useful as zygomycetous cellulase inducers. Moreover, $M$. corticolus presented higher CBH and $\beta$-glucosidase yields on SSF1 than SSF2, which also confirms the suitability of these plant wastes for cellulase production. In contrast, big differences were found in the cellulase activity of $R$. miehei on SSF1 and SSF2. Besides the slight CBH induction, the latter media provided about $4-5$ times higher CMCase and $\beta$-glucosidase activities.

In both fermentation systems, $\mathrm{CBH}$ activity of the isolates was significantly lower than that of CMCase (Table 1). It is known that activities of these enzymes complement each other lead to synergy [32]; therefore, elevated CMCase activity generally causes enhancement in $\mathrm{CBH}$ activity. For that reason, it is worth mentioning that despite the high CMCase activity, moderate $\mathrm{CBH}$ production was detected in the case of G. persicaria as compared to the other strains. Additionally, production of CMCase usually reached its maximum during the exponential phase (second day), while $\mathrm{CBH}$ and $\beta$-glucosidase reached it during the late growth phase (sixth day or after). Elevated CMCase secretion has also been described at the beginning of the growth of Aspergillus fumigatus AKB9, when CMC and 2-deoxy-D-glucose were applied as substrates in submerged fermentation [7]. On the other hand, extracellular $\beta$-glucosidase activity of the tested fungi was found to be considerably higher than their $\mathrm{CBH}$ activity, which is able to hydrolyze microcrystal cellulose moiety. A similar observation was recorded for mixed cultures of Aspergillus ellipticus and A. fumigatus in SSF [14]. The $158.3 \mathrm{U} \mathrm{g}^{-1}$ dss $\beta$-glucosidase yield presented by $R h$. niveus on the sixth day in SSF2 was about 1.74 times higher than those reported previously for this fungal strain (described as Rh. stolonifer) on wheat bran [31].

Wheat bran-based media have been reported as a good candidate for lipolytic enzyme induction in filamentous fungi $[6,10]$ including several zygomycetes $[12$, 17]. Since other plant-waste residues may also be able to increase the lipase yield, testing of them in both submerged and solid fermentations has continuous attention. The corn stalk and leaf materials examined in this study provided enhanced lipolytic activities (Fig. 2), which are comparable to lipase yields presented by other filamentous fungi in plant-waste residue-based fermentations [25, 34]. The lipolytic enzyme production of M. corticolus was slightly better on SSF1 than SSF2, which is similar to that observed for the cellulases. Among the tested fungi, M. corticolus seems to be the most promising fungus for cellulase and lipase secretion on corn stalk and leaf residues. Lipolytic enzyme production of $G$. persicaria on SSF2 was considerably lower than that of the other strains; unlike its remarkable cellulase yields [31]. This fungus had weak lipid hydrolyzing capacity in our previous tests, too [17].

It is well known that agricultural by-products can also be utilized for proteolytic enzyme production by filamentous fungi [35]. Different plant wastes were tested to induce the protease secretion of Aspergillus flavus, wherein wheat bran proved to be the best substrate [21]. Wheat bran is also preferred for protease production by zygomycetes and several Mucor, Rhizopus and Rhizomucor strains have been identified as promising sources of these enzymes [11]. Hydrolysis of peptidyl-pNAs showed 
induced chymotrypsin-like protease secretion by Rh. niveus under both SSF conditions. The secreted proteolytic enzyme exhibited the highest activity towards the chymotrypsin substrate Suc-AAPF- $p$ NA, indicating that it has endoproteolytic activity, and a preference for phenylalanine. Similar substrate specificities have been described for alkaline proteases from A. fumigatus [18] and Fusarium culmorum [23]. The enzyme from F. culmorum was considered to be a subtilisin-like protease, which implies that the extracellular proteolytic activity of $R h$. niveus may relate to fungal subtilisins. The saprotroph nature of the isolate may also strengthen this suggestion since the endoprotease activities of such fungi are mainly provided by subtilisin-like enzymes [9].

In conclusion, the cellulase and lipase production of the tested Mucoromycotina fungi proved to be inducible when corn stalk and leaf plant-waste residues were used in SSF conditions. Nonetheless, as we know, this is the first report on the protease activity of Rh. niveus under SSF using corn residues. Further studies are needed in order to set up the appropriate fermentation parameters through statistical methodologies, and to isolate and characterize the identified $R h$. niveus proteolytic enzyme.

\section{ACKNOWLEDGEMENTS}

The research of A. K. and M. T. was supported by the European Union and the State of Hungary, cofinanced by the European Social Fund in the framework of TÁMOP 4.2.4.A/2-11-1-2012-0001, National Excellence Program. We acknowledge Hungarian Research Fund (OTKA NN106394) for providing infrastructural and research facility.

\section{REFERENCES}

1. Ang, S. K., Shaza, E. M., Adibah, Y., Suraini, A. A., Madihah, M. S. (2013) Production of cellulases and xylanase by Aspergillus fumigatus SK1 using untreated oil palm trunk through solid state fermentation. Process Biochem. 48, 1293-1302.

2. Anwar, Z., Gulfraz, M., Irshad, M. (2014) Agro-industrial lignocellulosic biomass a key to unlock the future bio-energy: A brief review. J. Rad. Res. Appl. Sci. 7, 163-173.

3. Apprich, S., Tirpanalan, Ö., Hell, J., Reisinger, M., Böhmdorfer, S., Siebenhandl-Ehn, S., Novalin, S., Kneifel, W. (2014) Wheat bran-based biorefinery 2: Valorization of products. LWT-Food Sci. Technol. $56,222-231$.

4. Boyce, A., Walsh, G. (2012) Identification of fungal proteases potentially suitable for environmentally friendly cleaning-in-place in the dairy industry. Chemosphere $88,211-218$.

5. Chandel, A. K., Chandrasekhar, G., Silva, M. B., da Silva, S. S. (2012) The realm of cellulases in biorefinery development. Crit. Rev. Biotechnol. 32, 187-202.

6. Contesini, F. J., da Silva, V. C. F., Maciel, R. F., de Lima, R. J., Barros, F. F. C., Carvalho, P. D. (2009) Response surface analysis for the production of an enantioselective lipase from Aspergillus niger by solid-state fermentation. J. Microbiol. 47, 563-571.

7. Das, A., Paul, T., Halder, S. K., Maity, C., Das Mohapatra, P. K., Pati, B. R., Mondal, K. C. (2013) Study on regulation of growth and biosynthesis of cellulolytic enzymes from newly isolated Aspergillus fumigatus ABK9. Pol. J. Microbiol. 62, 31-43.

8. De Castro, R. J. S., Sato, H. H. (2014) Production and biochemical characterization of protease from Aspergillus oryzae: An evaluation of the physical-chemical parameters using agroindustrial wastes as supports. Biocatal. Agric. Biotechnol. 3, 20-25. 
9. Dunaevskii, Y. E., Gruban, T. N., Belyakova, G. A., Belozerskii, M. A. (2006) Extracellular proteinases of filamentous fungi as potential markers of phytopathogenesis. Microbiology 75, 649-652.

10. Falony, G., Armas, J. C., Mendoza, J. C. D., Hernández, J. L. M. (2006) Production of extracellular lipase from Aspergillus niger by solid-state fermentation. Food Technol. Biotechnol. 44, 235-240.

11. Ferreira, J. A., Lennartsson, P. R., Edebo, L., Taherzadeh, M. J. (2013) Zygomycetes-based biorefinery: Present status and future prospects. Bioresour. Technol. 135, 523-532.

12. Garlapati, V. K., Banerjee, R. (2010) Optimization of lipase production using differential evolution. Biotechnol. Bioprocess Eng. 15, 254-260.

13. Ghosh, B., Ray, R. R. (2011) Current commercial perspective of Rhizopus oryzae: a review. J. Appl. Sci. 11, 2470-2486.

14. Gupte, A., Madamwar, D. (1997) Production of cellulolytic enzymes by coculturing of Aspergillus ellipticus and Aspergillus fumigatus grown on bagasse under solid state fermentation. Appl. Biochem. Biotechnol. 62, 267-274.

15. Juturu, V., Wu, J. C. (2014) Microbial cellulases: Engineering, production and applications. Renew. Sust. Energ. Rev. 33, 188-203.

16. Kaur, B., Oberoi, H. S., Chadha, B. S. (2014) Enhanced cellulase producing mutants developed from heterokaryotic Aspergillus strain. Bioresour. Technol. 156, 100-107.

17. Kotogán, A., Németh, B., Vágvölgyi, C., Papp, T., Takó, M. (2014) Screening for extracellular lipase enzymes with transesterification capacity in Mucoromycotina strains. Food Technol. Biotechnol. 52, 73-82.

18. Larcher, G., Bouchara, J. P., Annaix, V., Symoens, F., Chabasse, D., Tronchin, G. (1992) Purification and characterization of a fibrinolytic serine proteinase from Aspergillus fumigatus culture filtrate. FEBS Lett. 308, 65-69.

19. Li, G., Chen, H. (2014) Synergistic mechanism of steam explosion combined with fungal treatment by Phellinus baumii for the pretreatment of corn stalk. Biomass Bioenergy 67, 1-7.

20. Miller, G. L. (1959) Use of dinitrosalicylic acid reagent for determination of reducing sugar. Anal. Chem. 31, 426-428.

21. Muthulakshmi, C., Gomathi, D., Kumar, D. G., Ravikumar, G., Kalaiselvi, M., Uma, C. (2011) Production, purification and characterization of protease by Aspergillus flavus under solid state fermentation. Jordan J. Biol. Sci. 4, 137-148.

22. Ng, I. S., Li, C. W., Chan, S. P., Chir, J. L., Chen, P. T., Tong, C. G., Yu, S. M., Ho, T. H. D. (2010) High-level production of a thermoacidophilic $\beta$-glucosidase from Penicillium citrinum YS40-5 by solid-state fermentation with rice bran. Bioresour. Technol. 101, 1310-1317.

23. Pekkarinen, A. I., Jones, B. L., Niku-Paavola, M. L. (2002) Purification and properties of an alkaline proteinase of Fusarium culmorum. Eur. J. Biochem. 269, 798-807.

24. Saha, B. C. (2004) Production, purification and properties of endoglucanase from a newly isolated strain of Mucor circinelloides. Process Biochem. 39, 1871-1876.

25. Salihu, A., Alam, Z., AbdulKarim, M. I., Salleh, H. M. (2012) Lipase production: An insight in the utilization of renewable agricultural residues. Resour. Conserv. Recy. 58, 36-44.

26. Sarkar, N., Ghosh, S. K., Bannerjee, S., Aikat, K. (2012) Bioethanol production from agricultural wastes: An overview. Renew. Energy 37, 19-27.

27. Sharma, D., Sharma, B., Shukla, A. K. (2011) Biotechnological approach of microbial lipase: A review. Biotechnology 10, 23-40.

28. Singhania, R. R., Sukumaran, R. K., Patel, A. K., Larroche, C., Pandey, A. (2010) Advancement and comparative profiles in the production technologies using solid-state and submerged fermentation for microbial cellulases. Enzyme Microb. Technol. 46, 541-549.

29. Soni, R., Nazir, A., Chadha, B. S. (2010) Optimization of cellulase production by a versatile Aspergillus fumigatus fresenius strain (AMA) capable of efficient deinking and enzymatic hydrolysis of Solka floc and bagasse. Ind. Crop. Prod. 31, 277-283.

30. Takó, M. (2011) Analysis of Beta-glucosidases from Zygomycetes Fungi: Purification and Characterization of the Enzyme, Molecular and Functional Analysis of the Coding Genes. Ph.D. Dissertation, University of Szeged. 
31. Takó, M., Farkas, E., Lung, S., Krisch, J., Vágvölgyi, C., Papp, T. (2010) Identification of acid- and thermotolerant extracellular $\beta$-glucosidase activities in Zygomycetes fungi. Acta Biol. Hung. 61, 101-110.

32. Teeri, T. (1997) Crystalline cellulose degradation: new insight into the function of cellobiohydrolases. Trends Biotechnol. 15, 160-167.

33. Thomas, L., Larroche, C., Pandey, A. (2013) Current developments in solid-state fermentation. Biochem. Eng. J. 81, 146-161.

34. Treichel, H., de Oliveira, D., Mazutti, M. A., Di Luccio, M., Oliveira, J. V. (2010) A review on microbial lipases production. Food Bioprocess Technol. 3, 182-196.

35. Yegin, S., Fernandez-Lahore, M., Salgado, A. J. G., Guvenc, U., Goksungur, Y., Tari, C. (2011) Aspartic proteinases from Mucor spp. in cheese manufacturing. Appl. Microbiol. Biotechnol. 89, 949-960.

36. Zhang, C., Pang, F., Li, B., Xue, S., Kang, Y. (2013) Recycled aqueous ammonia expansion (RAAE) pretreatment to improve enzymatic digestibility of corn stalks. Bioresour. Technol. 138, 314-320. 